\title{
Towards Reform of Land Acquisition Framework in India
}

\section{Sebastian Morris \\ Ajay Pandey}

W.P. No. 2007-05-04

May 2007

The main objective of the working paper series of the IIMA is to help faculty members, Research Staff and Doctoral Students to speedily share their research findings with professional colleagues, and to test out their research findings at the pre-publication stage

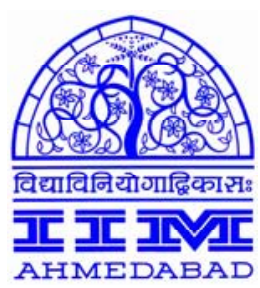

INDIAN INSTITUTE OF MANAGEMENT

AHMEDABAD-380 015

INDIA 


\title{
TOWARDS REFORM OF LAND ACQUISITION FRAMEWORK IN INDIA
}

\author{
Sebastian Morris and Ajay Pandey ${ }^{1}$
}

\begin{abstract}
We bring out the fundamental and more important problems with the current framework of land acquisition in India, regulations on land and the functioning of land markets. We argue that reform is overdue and the current framework would be unsustainable in a democracy that is India. Current land prices are highly distorted owing largely to regulatory constraints and the process of takings. Land acquisition more than any other factor is the most important constraint on development and especially in infrastructure development. We bring out the core elements of the reform - the need to define "public purpose" ex-ante for compulsory acquisition of land, the measures that would allow the market price of land to play its correct role, and the approach to valuation. We also argue for an independent valuer when compulsory taking is involved and methods of valuation to ensure that the land owner including the farmer gets the correct value for this land in both compulsory acquisition and in voluntary sale. We also argue the need for a parallel non-compulsory framework for acquisition and develop the key elements of the same. We also bring out alternatives to physical acquisition of land especially in the context of infrastructure development in central places.
\end{abstract}

\footnotetext{
${ }^{1}$ Professors at the Indian Institute of Management Ahmedabad, India email: morris@iimahd.ernet.in and apandey@iimahd.ernet.in respectively
} 


\section{SECTION I}

\section{THE PROBLEM TODAY}

Uncertainties, risks, delays related to land acquisition, protests and resistance on the part of the displaced have become the most important bottleneck for investments especially in the infrastructure sector. ${ }^{2}$ Land acquisition and rehabilitation have been issues around which much mobilisation and protest against the state has taken place in India and continue to do so. Indeed environmental protest that has a mass following also have their roots in the problems of land acquisition and rehabilitation. Thus if the problems arising out of land acquisition, rehabilitation and environment (especially environmental protest) are considered together then they account for the overwhelming cause of delays, cost overruns and high risks in projects today.

Typically people whose lands and habitations are taken over by the Indian state suffer much and their protests while ineffective result in much social loss and evokes the sympathy of the intelligentsia so much so that a significant anti-development orientation among people, especially the intelligentsia and (Non-Government Organisations) NGOs builds up. Such "anti-developmentalisation" has taken deep roots and has lead to significant support for externally arising post-modernist influences in Indian society. The situation today is such that almost no large project which has the potential to bring significant gains is possible without hurting the displaced and those whose lands are taken over, most of whom are poor. Development today is seen as being "anti-poor" in a direct easily recognised sort of way. Even if many other poor (usually in much larger numbers) gain out of developmental projects, the political basis for anti-developmentalism is large. In other words development projects in India violate the core principle of having to be at least pareto-optimal - i.e. not hurting some people while leading to income rises in many others. Without basic change in the law and the policy that makes land acquisition and rehabilitation at least pareto-optimal if not significantly better for those giving up land and being displaced, it is a forgone conclusion that growth and development would have to adjust downwards and most of the projects would continue to suffer delays and cost overruns while imposing much pain on the poor, or would not be taken up. [Morris, S., 2001]

While many scholars have brought out the inequities and violation of human rights in the land acquisition process ${ }^{3}$, there has been little attempt to understand its working either in economic and legal terms, or to find solutions. The discussion has either been around of the limitations of the working of the governmental machinery which have brought out delays in land acquisition, or in terms of the "oppressive character" of the modern capitalist state. This paper for the first time understands the problems of land acquisition correctly and in a way that leads to its solution through suitable change in the law and policy.

\footnotetext{
${ }^{2}$ If the recent spate of protests around land in Bengal, Orissa, Kerala, UP, and Maharashtra is indicative then a step up in such activities is inevitable.

${ }^{3}$ Cf.Fernandes, W. (1998) or PUCL(1989).
} 


\section{SECTION II}

\section{GENERAL PROBLEMS WITH REGARD TO LAND MARKETS}

\section{Imperfect Markets}

Land markets are not very close to being perfect. There are significant perversities in land markets, but the markets can be coaxed into delivering optimal results with appropriate restraints and regulation. The first insight is to recognise that no two pieces of land are the same (unlike in the case of most produced goods and services). But there is sufficient substitutability between lands, for most purposes, to allow a market to function and to deliver close to optimal results in most cases except when infrastructural services and exploitation of natural resources are involved. It is the exception that requires significant attention on the part of the state and policy.

\section{The Hold-Out Problem}

One of the important problems recognised with regard to the functioning of land markets especially in urban areas is the "hold-out" problem which economists recognise as one reason for the state to intervene in some manner. Imagine that a stretch of land currently occupied by individual houses, is being considered by a developer to build upon a mall or a shopping complex. Then the project to convert the houses to a mall is socially beneficial if the income emerging out of the new activity on the land is large enough to cover current values of the plots individually and transaction costs of so converting, the deadweight loss of the houses having to be demolished to make way for the mall, and to still leave a significant surplus.

The hold out problem provides one line of justification for the use of eminent domain or compulsory acquisition of land. Under eminent domain the state takes over the lands and hands them over to the new owner for the socially beneficial activity. While the "holdout" problem in this case could seem to justify the use of eminent domain, in reality there are ways to minimise hold outs. If in this case the law prohibits developers from offering differential prices for the base land, and ensures that all land owners are paid at the highest offered price, then potential 'hold-out' candidates know that they cannot coax large portions of the surplus out of the developer. Also they are forced to bargain collectively. Since the buyer has choices in other locations requiring similar aggregation, and groups of sellers have choices in many developers, the market would overcome the hold-out problem to a large extent, when subject to the regulation that every seller would get the maximum offered to any particular seller among the set of plots that were aggregated. There are of course details of defining aggregation, plots and sellers. ${ }^{4}$ that would have to be worked out put in place for such a framework.

\section{Eminent Domain and Public Purpose}

Another, perhaps the really important justification for eminent domain or compulsory takings, has arisen out of the notion of public purpose. Strangely the public purpose has not generally been adequately or clearly defined. The idea here is that if the public benefit

\footnotetext{
${ }^{4}$ Somewhat similar perversity exists when companies are taken over by a new management or owner. Minority shareholders under most stock-exchange rules have to be offered the price awarded to large stake-holders by the taking over firm.
} 
is enhanced significantly then the state has the right to overcome hurdles including obtaining land for achievement of the same. If public purpose is understood merely as enhancing the total net social benefit then virtually all socially viable projects justify the intervention of the state if there are barriers arising out of land to their achievement. Net social benefit per se does not justify 'public purpose' warranting the use of eminent domain. It would be correct to take the view that the compulsory acquisition by the state is justified only if in the realisation of a socially viable project specific land is required. The emphasis is on the word specific. In other words, it would be more appropriate to say that the specificity of land required for the attainment of public benefit justifies state takings or intervention.

The above two aspects in the use of land has lead to laws in democracies allowing for eminent domain (US) or compulsory takings (Australia, New Zealand, Thailand) in democracies. In all such cases the purpose in a particular taking can be challenged by interested parties to be settled in a court of law. That provision has allowed state action arising out the use of eminent domain from violating systematically the rights of citizens by the government of the day. ${ }^{5}$

\footnotetext{
${ }^{5}$ The recent Kelo versus the state in which the Supreme Court of the US ruled that private profit arising out the use of the land compulsorily taken over does not negate public purpose has created much uncertainty and to significant loss of the right to private property. Insightful commentators have claimed that the public purpose (railroads, ports, roads, dams and city improvements via due process) alone as was the case in the past should have merited application of eminent domain. Cf. Summers, Adam (2006). For a different view that the case was in keeping with the past practise and did not extend the domain of the state beyond a justifiable public purpose Cf. Echeverria, John D (2005).
} 


\section{SECTION III}

\section{THE INDIAN CONTEXT}

In India high population density and the age of its civilisation implies that it is very difficult to obtain land without displacing people in large numbers, or having to worry about loss of heritage sites.

\section{Agricultural Dependence and Surplus Labour}

Even today the marginal product of labour in agriculture is close to zero, so that many farms (especially of peasants and share croppers) are loss making if the total family labour is valued at marginal market rates in the busy season for similar labour. Much of household industry and service activities like rickshaw pulling can be considered as value added maximising rather than profit maximising. This means that if a capitalist calculus were to be used many farms would be loss making. Nevertheless they are highly efficient in the social sense since the surplus labour allows them to use more labour than capitalist farms maximising profits alone would do. They are best considered as value added maximising farms. The increased labour application results in yields per unit of land being generally higher than on capitalist farms ceterius paribus if such a comparison could be made. And socially this is desirable since land is the limiting factor and labour the surplus factor.

While in situations without disguised unemployment it would be right to value land at the net present value (NPV) of the rental yield of land, (or even the NPV (capitalisation) of the profits + rents arising out of land) when land is the limiting factor and labour is in surplus i.e. the capitalisation of the value added is the correct social value or price of land. This would mean that compensation would have to be much higher than is generally admitted. The market value of land in densely populated economies (when there is a flourishing trade in land and especially in lease markets) incorporates such higher values to a partial extent. Disguised employment also means that the people displaced by a project even when they are not landowners nor working directly upon the land, cannot be assumed to be able to find alternative employment. Compensation would have to be income protecting (and enhancing) rather than merely covering the cost of adjustment friction and displacement and relocation.

\footnotetext{
${ }^{6}$ Imputed profit would be he revenues less the cost of inputs and that of labour including that which has to be imputed, cost of capital, and rents on land at market rates, which is the reward for risk taking in a capitalist calculus.
} 


\section{SECTION IV}

\section{MARKET DISTORTIONS}

\section{High Transaction Costs}

The land trade in India is highly taxed with transaction taxes being as high as $14.5 \%$ in many states ${ }^{7}$. This would limit the trade in land and deals would be underreported in value to avoid payment of taxes at such high rates ${ }^{8}$. The annual transactions value to the total stock of land would be very small, thinning out the market, and interfering with the process of price discovery. Liquidity in the land market would be very low and the land mortgage market would operate only at a large discount ${ }^{9}$. Reverse mortgage in land would be all but absent.

Income taxes too affect the recorded price of land ${ }^{10}$. The variability in land prices is large and the large risks in land as an asset means that the gains in land deals are an overestimate of the true gains out of the business of land trading, because the risk adjusted return would be much smaller. But income taxes do not adjust for risk since losses in land deals are not feasibly written off against profits unless land deals occur as part of a company's business, and this is rarely the case. For neutrality with other assets it would be necessary to treat profits arising out of land purchase and sales as capital gains with low capital gains tax. When land prices have been generally moving upwards, the tendency to under record the price in sales would be greater.

\section{Adverse Selection}

The above problems almost entirely displace the small investor from taking positions in the land market with the intention to profit. He would buy or sell land out of need and not to hold it as a pure asset. This is because he would find it difficult to deal with mere 'agreements to sell or to buy' which larger players could hold to short circuit two transactions into one and reduce the transactions cost thereby. One of the important reasons for "mafias" in the land business is their ability to make such arguments. Another is that the regulatory arbitrage in land trade is stupendously large as we will bring out

\footnotetext{
7 "Stamp duty needs to be paid on all documents which are registered and the rate varies from state to state. With stamp duty rates of 13 per cent in Delhi, 14.5 per cent in Uttar Pradesh and 12.5 per cent in Haryana, India has perhaps one of the highest levels of stamp duty. Some states even have double stamp incidence, first on land and then on its development. In contrast the maximum rate levied in most developed markets whether in Singapore or Europe is in the range of 1-2 per cent. Even the National Housing and Habitat Policy, 1998, recommended a stamp duty rate of 2-3 per cent. Most of the methods to avoid registration are basically to avoid payment of high stamp duty”.(http://www.indianground.com/legal.aspx)

${ }^{8}$ Indeed in response to such high transaction taxes, a method of avoiding taxes had developed in Andhra Pradesh, for instance. Two parties involved a land transaction would make an agreement to sell, for a consideration. Then a 'dispute' would be presented in a local court, and the court would decree the ownership of the land to which the parties would agree. Since now the ownership is based on a court decree, no taxes needed to be paid!

${ }^{9}$ During price booms though such transaction frictions would tend to be masked. It is in the trough of real estate cycles that the perversities and inefficiency in transactions is revealed. ${ }^{10}$ Other distortions arise from the Urban Land (Ceiling and Regulation) Act 1976, Rent Control Act and heavy rates of municipal taxes on usable property. These are well recognised in the discussion.
} 
soon. Modest taxes would have allowed many more including small players to actively participate in the land market. In such circumstances the recorded value of land would be a gross underestimate of the true value of land. The compounding effect of this factor and the fact of disguised unemployment referred to earlier is for the recorded price to be considerably lower than the true value of the land to the current cultivator.

\section{Poor Record of Property Protection}

Another depressant of the market price of land arises out of the poorer protection of landed property. There is considerable variation in the protection actually realised with regard to landed property across the country. There is much lacunae in the protection accorded to landed property arising both out of the law and its practice. ${ }^{11}$ There is almost no person who does not know of a close relative who was cheated out his /her land due to illegal /forcible occupation, or lack of clear title at the time of purchase. Indeed land in the urban fringes today, even when plotted, is most difficult to hold on to unless the land is in occupation by the owner or his agent. That makes most middle class people buy flats rather than land to make investments in real estate even if that results in unoccupied houses and flats, or in renting out of flats at very low returns.

\section{Problems of Title}

A related important depressant of land prices in relation to value is the lack of clarity to any title on the land unless the land is obtained from the state. Technically any purchaser of landed property takes a large risk since problems with the title are on his account even though he may not have been aware of such problems despite his best efforts and due diligence at the time of purchase. This arises because the land records that are relevant in determining the title can go indefinitely backwards, and there is no option to a private person to "commutate possible objections to the title" by appropriate legal action and notification. Thus a holder of land cannot register his land with a particular notified authority with the intention of commutating possible objections to his title through announcement and through due legal process carry out the same to establish his title with near absolute clarity. Since this facility is not there, there is always a risk that a seller does nor have clear unencumbered title to the land. This puts a downward pressure on the price of land in relation to its true value since the "risk of title" is high in India ${ }^{12}$. The lack of proper land records, the difficulty to access them further compounds the problem.

\footnotetext{
${ }^{11}$ The poor record of the state to protect landed property, may itself have resulted in underworld connections being used by owners to recover properties, typically occupied. Rent control acts, gave for too much power to tenants, and getting rid of tenants for occupation by other tenants or even by owners was a nightmare in most large cities. The one sided rent control acts had in an earlier period all but killed the market for rented housing. It also resulted in high risk being perceived by property owners with regard to possession of land and houses given on lease or rents.

${ }^{12}$ Thus "India's property title system and market practices present considerable difficulties in establishing clean title to property. The deeds registration system is not guaranteed by the State and is inconclusive; typically leaving buyers with 30 years of title deeds to assess. Customary rights and community property rules differ by religion and location and present a myriad of complications. Anecdotal evidence from legal advisors indicates that the level of fraud in Indian real estate transactions is very significant; and the court system is notoriously slow". (http://www.firstam.com.hk/newsletter/fam-e-news0206_2.htm ) in a report that added India to the list of countries where First American was willing to insure against title risk.
} 


\section{SECTION V}

\section{REGULATORY CONSTRAINTS AND LAND VALUES}

In land more than in other businesses the value and hence the price is affected in many ways by regulatory restraint and control over use. It is only now that estimates of these are being made by valuers and the impacts are stupendous by even the most conservative estimates. Typical regulations include besides zoning, land use restrictions, imposed densities and building bye-laws. Most of these arise in the urban context and to some extent are "inevitable" if urban planning has to take place to overcome the large negative externalities and value loss than can result from haphazard and unconstrained land use: While zoning in a way that is not too orthogonal to the market would enhance values, most of the density restrictions as also the density enhancements may on a net basis be subtracting values unless they result in greater use of public transport. In India severely restrictive low densities (floor space indices) have been imposed at very large social costs, which include inter alia making low cost public transport unviable.

\section{NAC Value and Prices}

In India perhaps the biggest depressionary factor on agricultural land arises out the restrictions (ban) on use of agricultural land for non-agricultural purposes. "NonAgricultural Use Clearance” (NAC) from the local /state government is necessary before land can be considered for other use. Consider for instance the land of an area (A) which could potentially have been put to use in non-agriculture say for urban housing and related activities. It is convenient to think in terms of annulus around the periphery of city of built up area B. See Figure 1.

Now if B is entirely built up and A is entirely agricultural currently, the value of a unit of land in A $(\boldsymbol{V})$ is the rental yield (or value added yield) of the land in agriculture $\left(\boldsymbol{R}_{\boldsymbol{a}}\right)+$ the probability of the land being used in non-agriculture $(\boldsymbol{P}) \cdot$ the rental value of the land in non-agricultural use $\left(\boldsymbol{R}_{\boldsymbol{n} \boldsymbol{a}}\right)$. Now $\boldsymbol{P}$ is a function of the growth rate of the urban area and $\boldsymbol{R}_{\boldsymbol{n} \boldsymbol{a}}$ is typically many times usually 10-20 times higher than $\boldsymbol{R}_{\boldsymbol{a}}$. Thus for an annulus like B in the immediate periphery of the built up area $\boldsymbol{P}$ is large (say 0.3 ) anywhere in A so that the larger value arises out of the second factor. So if $\boldsymbol{R}_{\boldsymbol{a}}$ is 1 and $\boldsymbol{R}_{\boldsymbol{n} \boldsymbol{a}}$ is 15 then $\mathrm{V}$ is $1+0.3 \cdot 12=5$. Now if there is a compulsory taking of a portion of the land $\boldsymbol{a}_{1}$ then its value at market price would be close to 5 (pre taking price), and post taking the value would only rise by the amount of value creation due to infrastructure provision and zoning etc, assuming that these are functional and only such as to eliminate negative externalities while enhancing values otherwise. There is what is usual in most countries since there is usually no `blanket’ restriction or ban.

Now consider the situation created by the need for NAC as in India. Pre taking since there is a requirement of NAC the probability $\boldsymbol{P}$ is close to zero. This is so if the grant of NAC is conditional on taking or linked to taking of parts of the area in question or in having to show proposals for non-agricultural use. Therefore the pre-taking price is just a little above 1 . Now post taking the price would be $1+1 \cdot 12$ which is now 13 , even neglecting the value creation aspect due to aggregation and infrastructure provision. [The $\boldsymbol{P}$ is one since areas like $\boldsymbol{a}_{2}$ and $\boldsymbol{a}_{3}$ in this round are denied uses beyond the agricultural]. This is 
the price that post taking of a1 the owners of $\boldsymbol{a}_{12}, \boldsymbol{a}_{13}$ etc would see if they got the NAC along with the taking of $\boldsymbol{a}_{\mathbf{1}}$. The new owner of property in $\boldsymbol{a}_{1}$ would see price of $13+$ the value creation. This we may call the "regulatory arbitrage" arising out the government bundling the decision of NAC with taking, and not generally granting NAC otherwise.

\section{Requirement of NAC and Regulatory Taking}

NAC is not normally granted to a farmer who wants to continue to use the land for agriculture while looking for a buyer. NAC is given (when no taking is involved) typically only to the owner who comes up with a concrete proposal for putting the agricultural land to use in non-agriculture. Therefore, the farmer cannot benefit out of the value accretion that arises out of the probability of its use in non-agriculture even when no taking is involved. The requirement of NAC therefore bestows large rents to the purchaser of agricultural land at the cost of the agriculturalist who normally cannot look to getting NAC for his land. This creates therefore the large difference between the seller price and post sale price of land. [There is some moderation to the extent that the farmer is able to bargain in part of the price difference, anticipating the use for non-agriculture by the buyer when no talking is involved. When taking is involved the new owner pockets the value of aggregation, the jump up in prices on account of non-agricultural use being now possible and the associated price depression (regulatory arbitrage), entirely].

These pure transfers are a major distortion of the regulation of NAC and is against the interest of the farmer. It amounts to state mediated transfer to the buyer from what were legitimately the farmer's even when no talking is involved. This feature of Indian regulation more than anything else depresses the price of agricultural land from true values and creates a vast difference between post and pre-change over prices. Equally importantly it creates a major distortion in the investment decision related to the project. Typically since the entrepreneur/investor in the project seeks to maximise the total return to the project, in this case of a significantly large transfer he would be maximising the earnings from the project proper plus the transfer of value on account of the land especially if the land is acquired through compulsory taking.

Since in NPV terms the transfer could be quite significant in relation to the total value of the project, inappropriate choice of the project could be made. Sub optimal project choice is the result, as also the acquisition of excess land leading to social inefficiency. In the recent SEZ investments the arbitrage of regulation on land and its use is one of the important reasons for 'entrepreneurial' interest in SEZs. Projects based on compulsory acquisition typically acquire excess land that remains unutilised for years - public sector units, educational institutions universities, other institutions have all exhibited this phenomenon. The (perverse) incentives to do so are obvious given the vast difference in the price pre and post acquisition. Equally importantly when the land cost is not endogenous to the budget of the project as a whole, there is a tendency to ask for excess land especially on the part of PSUs and autonomous institutions. Indeed in the case of many of them the value of the excess land may rival the NPV of the value created by the project itself!

\section{Other Restraints}

Another factor that depresses the price of agricultural land is the ban on purchase of agricultural land by people other than farmers, that obtains in some states including 
Maharashtra and Gujarat ${ }^{13}$. This does not allow the higher prices that buyers other than traditional farmers could have paid for the land. Lands used as orchards, farm land near tourist locations, scenic land, lands suitable for farming and habitation by middle and upper middle classes, farm lands with easy access to central places and areas with much potential for gentlemen farming or corporate farming are so affected. It also leads to much under investment in land for farming and for dual use of land. The urban rural divide is accentuated by such restrictions, and clearly the farmers are most hurt by these restrictions, and builders and other land developers with connections with the decision making authorities are the gainers. Most importantly the social losses are large since the price of land is unable to play the role that it must - allocating land among its many uses to the best social use.

\footnotetext{
${ }^{13}$ This law which came about as a knee jerk reaction to sale of agricultural land to nonagriculturists who could then hold the same and convert to non-agriculture use as outlined above to make large gains. (It would have been appropriate to correct the first distortion of requiring NAC itself).
} 


\section{SECTION VI}

\section{PERVERSITIES IN COMPULSORY ACQUISITION IN INDIA}

Today ${ }^{14}$ the government typically goes by market prices as recorded which as mentioned before is deeply depressed for various reasons including the regulatory restrictions in land use and purchase, the most important of which is the requirement of non-agricultural use which is given typically with the taking on aggregation by a developer.

\section{Unfair Process of Valuation}

Unlike in other countries that practice compulsory takings, in India the "fair value" is typically decided by the taker (government) itself. This is akin to "I cut the cake and chose the piece too", which is clearly unfair to the person whose land is being taken. In some countries notably Thailand the valuation is determined by independent licensed valuers and in other countries the valuation can be determined by both parties to result in convergence. Since against the use of the eminent domain there ought to be safeguards to ensure a fair valuation this combination of the taking and valuation roles is a perversity that is antithetical to democracy. It is the survival of the practice of an imperial government that did not see its interest to lie in the country or its people. Indeed it is typically the collector who values both the land and identifies the land for take over, not that it would have made a difference if different departments within the government dealt with the two aspects. The taking of excessive land, undervaluation, ignoring principles other than the one officially specified in valuation, ${ }^{15}$ ignoring idiosyncratic value of the land, working with one shoe fits all principle, ignoring the particular importance of land in a land scarce labour surplus economy are all not merely possible, but very much part of the practice today. And these interalia arise because government is both the authority that decides the takeover and the valuer. Indeed the discipline of valuation of land and real estate is poorly developed in India since the most important land related decisions and valuations were internal to the government ${ }^{16}$. And equally importantly, since the regulatory overload on the land market is large - NAC, restrictions in land use, restrictions on who can buy etc- the market aspect of valuation is poorly developed and so also is the discipline. Even with the best of practice, with compulsory takings, the tendency of the government to implicitly transfer rents to the project at the cost of landowners by prior regulatory taking cannot be excluded. Even in the US, rarely though, this has happened. That is now widely recognised in the debate on 'fair value' determination. In India the prior depression of the land value and price being taken over is

\footnotetext{
${ }^{14}$ Before the 1984 amendment to the Land Acquisition Act 1885, the government decided upon the price without reference to the market. This had inter alia resulted in lands being acquired at throw away prices in the periphery of cities!

${ }^{15}$ Currently these go by recorded "market" prices. Even this 'constraint' on the valuer is a recent phenomenon - post the 1984 amendment. Before the amendment, the collector was free of any constraint in valuation.

${ }^{16}$ Interestingly there is not even a single business school that has courses in real estate, land development or valuation. Not surprisingly so since there was little demand with the underdevelopment of the sector and the poor development of the land market. This would of course change as the real estate markets in the suburbs open up based on construction for the middle and upper middle classes.
} 
the norm enshrined in the law and practice, and its non-recognition as such is very much a result of the government being both the taker and the valuer.

\section{Natural Resources and Valuation}

There are further inequities in the price given to land holders in compulsory takings. Consider for the moment that semi arid land producing at best one crop is being taken over. The approach of the government is to fix a price based on the recorded price of the base land and to then cover the cost of assets on the land such as a house a well or a tree based on detailed survey and assessment. The natural resource tied to the land is not typically valued. Imagine that in this semi arid area there are a few scattered pockets of land typically no larger than a few hectares that overlie underground aquifers. Government covers the cost of the well, but not the resource (ground water) which given its scarcity and rarity in this area is of very large value. Indeed since the area is land abundant the value of the land with such an aquifer above the base land would be greater by many times ${ }^{17}$. In such a situation the bulk of the people would be "willing" to give up the land (especially when far from urban areas. This is so, because in such areas, the land values may have remained stagnant, and barring stamp duty there are no other incentives to record law prices. So a solatium of $30 \%$ above recorded prices may take the land values closer to the "true" values. But those occupying lands with aquifers would strongly resist takings. Clearly then going by reference to the market prices of base land in this case is not adequate but the government needs to go by the market price of the endowed land $^{18}$ or provide due allowance for natural resources like water.

\section{Intangibles Not Fully Recognised}

Intangible assets and resources like nearness to markets and central places to roads and highways, to railway stations and other public facilities would have to be explicitly recognised when the valuation is on a price for "base" land. The valuation models for true assessment of the same even in the best of cases when land markets are allowed and encouraged to function are difficult and require professional skills. In the Indian situation where the land market is highly distorted and depressed, in the pre-taking stage it would be even more so. Most importantly in compulsory takings even after all distortions in price formation are overcome, the case of higher of the values arising out of multiple valuation models need to be considered for award.

\section{Capitalisation of Value Added for Compensation}

We have already mentioned that in most parts of India land is the limiting factor (both in the static and dynamic sense, while capital is limiting only in the static sense), and labour is in surplus so that the agricultural value of the land goes beyond the capitalisation of the rental value of land in agriculture and is closer to the capitalisation of the value added in land. In such situation of disguised unemployment many more people than who give up their land are adversely affected in any large scale taking. People in the interstices of the economy based on land, people like rickshaw pullers, potters, menial labourers, domestic servants are also displaced when entire villages or substantial parts of the village are taken over and would have to be resettled. This aspect is not explicitly recognised in the

\footnotetext{
${ }^{17}$ In the Positra area of Gujarat where the government was planning to acquire land for an early Special Economic Zone (SEZ), the price of such lands endowed with water over others dependent entirely on rain fed cultivation was more than 5 times.

${ }^{18}$ Assuming that other distortions such as requirement of NAC and other unnecessary regulations are not there.
} 
LAA and the rehabilitation policy of the state. The resettlement and rehabilitation even when finally such people are covered comes after much negotiation and contest and more often as an accommodation rather than as a right of the people displaced. 


\section{SECTION VII}

\section{PUBLIC PURPOSE AND COMPULSORY ACQUISITION}

\section{Any Purpose as Public Purpose}

The public purpose in compulsory takings in India today is in effect any purpose the government of the day chooses to use the land for. At least in the British days when the public purpose was also not defined it was constrained by ownership which could only be government or its parastatals for lands being taken ove under eminent domain. Since the amendment of the Act in 1984, the constraint that government owns the land post acquisition has gone with the incorporation of the "company" in the act. Since the act of acquisition cannot be normally challenged (only the compensation provided can be debated) there is no recourse from the government of the day choosing to interpret "public purpose" in an all encompassing manner that includes every possible economic and non-economic activity. In all other societies that the author is aware of where there is compulsory taking the purpose can be challenged in a court of law. In India the only basis to challenge acquisition post the act is the inconsistency between the stated purpose and the actual use to which the land has been put to.

\section{Dysfunctional Ownership Limitation}

Before the amendment to the LAA there was at least one constraint on the government and it was that the land taken over would be owned by the government. In the preindependence period this constraint was meaningful becasue much of the land required for commercial activities was outside compulsory acquisition, since the government limited itself to governance functions, town planning and infrastructure. In the post independence period, since the government entered into many areas including commercial activities like trade and manufacturing the scope of compulsory acquisitions increased greatly. Furthermore the greater pace of growth, and the deep diversification of the economy that took place under planning greatly increased compulsory acquisitions and the inequities and hurt that was imposed on Indians could only have increased dramatically since the government was not even constrained to pay "market rates"19.

Since amendment to the LAA in compulsory acquisitions in 1984 the discretionary power of the government has gone up in several ways: The period from announcement of intent to acquire to possession has been shortened. And most importantly government can acquire land for companies - i.e. even if the land is to be owned and used by private companies or any party for that matter. But since the public purpose is not defined in any case, this has opened the door wide for government to acquire land for many reasons. Thus lands have been acquired for housing colonies, ashrams, manufacturing enterprises, entertainment establishments, service industries etc. Indeed the working framework is one where all large investors bank upon government to acquire land for them. The considerable transfers that this results in, both on account of excess land being asked for and acquired, and because of the vast depression in prices due to prior regulatory restraints $^{20}$ are very large ${ }^{21}$. Today such inequity portends to create large-scale protests and dissatisfaction and make an otherwise democratic state system oppressive.

\footnotetext{
${ }^{19}$ It is estimated that over $50 \mathrm{~m}$ people may have been displaced and only inadequately compensated or rehabilitated in this period.

${ }^{20}$ When significant such restraints have been called "regulatory takings" in many other democracies and when so ruled have forced governments to award fair compensation.
} 


\section{Public Purpose Requires Definition}

The law needs to define public purpose and it is possible to do so with a fair degree of coherence. Such prior definition (and the delimitation that comes with it) would reduce the policy and regulatory risk associated with land acquisition and hence in investments in general. The alternative to leave the public purpose undefined but to allow challenge in a court of law while better (fairer to the land owner) than is the case in India (where the "public" purpose cannot be challenged) would nevertheless not lead to a substantial reduction in the risk. In the US a framework that does not attempt to define public purpose but allows challenge in a court of law has created much avoidable litigation around the law despite the large role of practice and precedent in the determination of the law. In India the costs of leaving the public purpose undefined would be even more severe. Given that Indian courts can be easily gamed, and they are already overburdened with cases, to not define the public purpose would be tantamount to swinging from one extreme - unfairness to the land owner to another - unfairness to the investor or project promoter; and with no reduction in the risk. Although in no country has the public purpose been defined in the law they have been allowed to develop especially when tort law and the practice has tended to inform current decisions and rulings. As such in these countries - US, UK, New Zealand there is fair understanding of what would pass muster as public purpose.

\section{Public Ownership is Not Public Purpose}

Defining public purpose in terms of ownership is not the right thing to $\mathrm{do}^{22}$. If private businesses are to provide public services and increasingly so in the future, public ownership of the land as constituting public purpose would not be useful. It would be absurd to not allow a private BOT or annuity operator to not have recourse to eminent domain to acquire land for a dam or a road while the state is free to do $\mathrm{so}^{23}$.

\section{Requirement of Specific Land is Crucial}

Public purpose has to be just that and an economic consideration of public services illuminates the problem. Thus all projects that require specific land (dam site, deep water site for port, and road expansion where the land required is adjacent to the existing road, a bridge site, flyovers and elevated highway, rail right of way) would, because alternate lands are quite unsuitable, be subject to market failure in their land dependence. Hence there is meaning in lands for such purposes being acquired under eminent domain.

\footnotetext{
${ }^{21}$ Today as the economy has been considerably liberalised, governmental discretion over land and its use - land awards and grants, use clearances and pricing of land have become the source of much rent. This discretion which has given government much power to reward and punish bypasses all approval of the legislature.

${ }^{22}$ Even in a situation when all public services are provided by the state, ownership of land by the state is not a sufficient condition, since public services provision would only be a subset of the actions possible to the state.

${ }^{23}$ The state acquiring, and owning the land but holding it on lease to the private party introduces other risks and opens the whole question of the lease value. In the actual determination of the lease values much scope for transfers and "rents" would exist and the government of the day can a priori impose large risks on projects. This would make all projects including pure manufacturing projects where there is no market failure into high-risk projects with the risk emanating from the exposure of the party to land lease risks. Besides the price of the lease the risk emanating from resumption of land by the state is always there.
} 
Similarly in the case of minerals and other natural resources specific land would be required. Protection of nature (actions such as creating biosphere reserves and nature parks, wild life preserves) and of heritage would require lands to be taken over. And sometimes lands even when not taken over to be subject to regulatory restraint (non-use in activities that are injurious to the protection of nature and of heritage) necessitating use of eminent domain. Much the same can be said about protection and preservation of homelands for tribals and such other peoples of a culture and level of development that warrant such protection.

\section{Physical Networks}

The issues of whether specific land is involved in highway/railway construction, and the identification of the same becomes important. Conceptually for any new alignment the requirement of lowest cost (of construction and operations of traffic, of displacement) and the need to connect up so many central places on the way can be cast in the framework of maximization of net benefits of the highway /railway. But such analysis while feasible could give different results and much would depend upon the basis and assumptions made, and these may not be good enough to lead to elimination of a large number of possibilities especially at the micro-level. Therefore it would be better for the government to accept the current practice with its assumptions, concepts of highway/ railway engineers ex-ante. But the practice has to specified as a code in the rules associated with the law, so that due process can be used to justify the identification of particular lands. With such process safeguards eminent domain can be used even in the case of new alignment of roads /railways/ pipelines/ canals/ waterways/ electricity transmission networks etc.

\section{Public Purpose in the Urban Context}

In the urban situation, clearly, specific lands required for establishment for intra city and intercity transport networks which have only limited leeway so that the ex-ante basis laid out by the departments charged with these responsibilities ought to be acceptable. Much the same is true of cable, gas, electricity, sewerage, water and other networks. Housing linked to the operation and maintenance of these assets is justified only for field employees.

\section{Industrial Estates and Market Places}

Governments would like to acquire land for industrial estates but typically many lands could have been considered for the purpose and hence specific land is not required. Much the same can be said for lands for institutions, housing, commercial development and for sale or allotment to favoured groups such as officers, academics and journalists. Therefore no public “public purpose” justifying eminent domain is involved here.

On the other hand land for market development (municipal markets, vegetable markets, hawkers yards) in a area where there is no market can and should happen only in central places and as such specific land is required. Market expansion would obviously require specific lands. Similarly lands for gardens, parks, and parking (in areas of the city that were developed in the pre-mass automobile era would require specific land. Since every case of public purpose cannot be specified (ex ante), and yet the need to describe public purposes and delimit the same is large, it would be appropriate to provide a special window in the law for government to bring in a public purpose and eminent domain that is beyond the specified list. And the government can announce the same, invite challenge and overcome the same in a court of law and then go ahead with the use of eminent 
domain. On the other hand when the government chooses to acquire land under public purposes mentioned in the act it should be able to go ahead with the onus being on the challenger to prove that public purpose is not involved.

\section{Revealing Project Data}

In all cases the total social value being delivered would have to be justified in a social cost benefit analysis, where the deadweight cost of displacement and loss of existing assets /income (but not the additional transfer payments involved) is considered as a social cost. This would imply that government / developers share the social cost benefit analysis of investment projects for public purposes (i.e. when specific land is required and eminent domain is used) with the public ${ }^{24}$. This would be consistent with the idea that the legislature alone should have the power to approve government budgets. [And if the idea of legislative sanction in its spirit has to be adhered to, even off budget transactions like contingent liabilities, and land acquisition payments need to have legislative approval/ or be capped]. Such transparency imposed upon government would also be consistent with the "Right to Information" and with the advancement of democratic processes.

\section{Additional Windows for Eminent Domain}

The use of eminent domain and regulatory restraints (takings) would when left unconstrained result in a perverse incentives on incumbent governments to use both restraints on land use and land acquisitions to lower the cost / increase the reported net benefits of projects and investment proposals that they choose to promote. Governments face a trade off between taxation and payments for land acquisition. But since taxes are voted and acquisitions (and contingent liabilities) are not,there is a perverse incentive to undervalue land or use regulatory restraint (takings) to lower land values, rather than taxes to support its expenditures and projects. This difference is most crucial and as much as in the case of contingent liabilities and guarantees there ought to be "caps on" the government using the power of eminent domain. Unlike in the case of contingent liabilities though, a risk weighted cap is not possible in the case of land. But with fair and independent valuation enshrined in the law, the perverse incentive to use eminent domain and regulatory takings is reduced considerably. And if public purpose too is specified in the law then the abuse of public purpose is quite unlikely. In order to allow for public purpose acquisition which may not have been anticipated in the law we have already said that a special window (to be rarely used) need to be provided. Alternatively or additionally governments must have the option of taking a project (a large project of great importance) with its land acquisition proposals and compensation to the legislature for sanction.

\footnotetext{
${ }^{24}$ The only possible exception to this rule would be when national security is involved, as when say on air-base or submarine harbour is being planned.
} 


\section{SECTION VIII}

\section{FRAMEWORK FOR NON-COMPUSLORY ACQUISITION}

In India today there is no framework for private acquisition of land. There have been some instances of private parties in a hurry not going through the LAA, even for projects of significance especially when the government of the day was not friendly to the group. Nevertheless the general trend has been that the pressures on the government of the day to acquire land for investment by private parties, even when no infrastructure is involved, has been very high. And few state governments including those that are pro-poor and pro-agriculturists can avoid offering land to attract investment. Acquiring land privately can become a nightmare for the party in question especially when large amount of land is required, and yet not result in significant benefits to those giving up land. The problem of jump up in value due to prior regulatory restraint (NAC requirement), and the enhancement of the hold out problem that it results in typically enhances the risk in private acquisition of good agricultural land.

Worthy parties who are focused on investments and not on playing the regulatory arbitrage game are particularly vulnerable Adverse selection cannot be ruled out in such cases. It goes without saying that the first and necessary step to overcome the problem is to allow a well functioning land market to develop. That would mean removal of all unnecessary restraints and constraints on land use, sale and purchase already described earlier. To further ease the problem of hold-out, the framework of a register to declare intent to buy land privately along the lines mentioned below can greatly ease the burden of acquisition and ensure fair values to those having to part with their lands. Such registers should work to greatly reduce transactions cost if a specified threshold say a 80\% land area and 75\% owner's agreement implies the agreement of all. Such a limit need be specified only when the fragmentation is very large and of the order of 30 or more units. Where lesser numbers are involved the hold out problem is not severe and the transactions cost not large, and deals have a high probability of going through. Hold out is possible but the promoter has the option to go to other such areas at little cost since no specific land is required. Where specific land is required then in any case eminent domain would apply. Appropriate safeguards such as considering all pieces under a use being considered as belonging to a "single owner" for determination of threshold would have to be specified in the framework. This would reduce the probability of the hold out while leaving the sellers to come together to bargain to obtain for themselves some of the economies in aggregation and in the new land use. 


\section{SECTION IX}

\section{ALTERNATIVES TO LAND ACQUISITION}

Much land currently acquired by the government especially municipal and town development authorities may be quite unnecessary. Thus in contrast to practise in many cities, the "TP scheme" of the Ahmedabad Urban Development Authority (AUDA) is an easy way to planned growth of the city without acquisition of the entire planned area as such and vastly reduced transactions cost. Here acquisition is net rather than gross.

\section{"TP Schemes”}

The system works in the following manner. The AUDA identifies a certain large region say on the western outskirts of the city for further urban development. Imagine that the current use of the land is largely for agriculture and residences. In the master plan the same area is demarcated into roads, public parks and gardens, areas for other public utilities and water bodies etc and for possession by the AUDA itself. And the rest is available for private occupation subject to land use restrictions -floor space indices (FSI), zoning, and building bye-laws. The public land use plus that desired by the AUDA for future sale and use is restricted typically to about $30 \%$ of the land being brought in for planned urban development. This means that each plot is shrunk by $30 \%$ to make the space for 30\% public land use and municipal ownership, leaving the owners with their current lands which are now smaller by $30 \%$. In the layout most plots do have the same neighbours as before and substantial assets like houses generally do not have to be demolished. The "TP scheme" is then put up for the public to bring their individual objections, and accepted in due course. All land owners gain since there is no land transfer - only net public land transfer to the government. From the government's point of view there is little risk and contest and the government does not have to pay for the land. The value creation is implicit in the act of town planning which if functional can create much value.

Additionally, given the NAC requirement for use out of agriculture, the sudden high jump up in value often as much as ten times means that those whose lands are so incorporated into the urban area gain enormously since the regulatory arbitrage as explained before is large. Even without the regulatory arbitrage the value increase on account of incorporation into the town with access to all urban services would make feasible such an approach. The regulatory arbitrage currently makes the AUDA approach unfair to those areas (and their owners) which could have been used for the extension of the city but is not as in the eastern periphery of the city. Without regulatory arbitrage the implicit transfer from those whose lands are is not incorporated to those benefiting out of "TP schemes" it is would be small and limited to the difference caused by the provision of infrastructure and to the value addition in (appropriate) zoning. ] If NAC is abolished and TP schemes are practiced, there is considerable scope for incorporation of land into urban areas without the many distortions and dilatory processes and litigation that takings and resale involve. It would also be immeasurably fairer than is the current practise. 
"Implicit” Acquisition in Road Widening

Similar approaches are possible elsewhere for instance in highway widening. Imagine that a highway with much ribbon development along its length is sought to be widened and made into an expressway with limited access to allow for fast movement between the two cities it connects. The government would face high risks and costs to takeover land and build the road, given that much ribbon development has already taken place. Typically in ribbon development the plots just adjacent to the highway would be high priced with the prices falling off steeply from the first to the interior plots. Often the third plot from the highway without access to a motorable road can have a price as low as a third or less that of the plots on the road. This is because unplanned ribbon development in restricting the access of the interior plots to the road destroys social value, while steeply enhancing the price of the plots having access to the road. Would not the market have resulted in a shift from ribbon development to more broad based corridor development? The very high values of the plots adjoining the road results in much of the surplus in economic activity being drawn out in the form of rents. Thereby the economic potential of the road itself to bring about development of the area is considerably attenuated. Seemingly there would be significant returns to aggregators, i.e. those who can buy up simultaneously interior plots and small pieces of land on the road to provide access of the interior plots to the road. But such measures would require a thriving land market with low transactions cost. Only bigger players who can operate at a larger scale could normally carry on such activities. The practise of land for land to provide access to the interior would not work since those giving up land on the road would be losers ${ }^{25}$. Similarly since much ownership of land is bundled with the economic activity and to homesteads there would be systematic erroneous valuation of returns to the economic activity, generally tending to either overvalue or undervalue the same.

In such a situation one option for the government (if there is sufficient potential for development in the area on either side of the road), is to develop an access (subsidiary road) along with the expressway so that fast access from any point in the corridor of the expressway to the center of both cities is possible. The lands for the expressway, such access roads and cross roads besides for other public amenities can be identified as constituting say $10 \%{ }^{26}$ of the land corridor and the same can be plotted out, to shrink all plots proportionately (or even disproportionately leaving their topological relationship broadly unaltered. This would certainly result in value appreciation (assuming that the access and subsidiary roads are built) without having to acquire the entire amount of land. Only compensation to cover the cost of buildings that would have to be razed to make way for the roads need be provided. Such an approach would also allow the government to avoid bundling commercial development merely to make a socially viable project financially viable. With this approach the project would be financially viable since the cost of the road would be limited to the construction cost while the otherwise very high cost of acquiring the land adjacent to a road under prior ribbon development would have been avoided.

\footnotetext{
${ }^{25}$ This is the "norm" in Kerala. As a result, ribbon development has only got enhanced and has choked the roads, and imposed impossible 'land cost' on the state attempting to widen roads. Typically the land for land principle brings out perverse behaviour on the part of those on the road; they show a propensity to build around footpaths to the interior plots preventing motorised vehicle access possible by widening such footpaths. This perverse behaviour is entirely rational. ${ }^{26}$ When the cities in question that the expressway connects are large, and growing rapidly, the corridor along the expressway where values are enhanced can be expected to be broader.
} 
Use of TDRs

We now consider another approach that can considerably lower transactions cost of obtaining land for public purposes that enhances social value. Thus in the very same situation of converting ribbon development to corridor development an alternative possibility is to lay out the land required for public purposes - the expressway, subsidiary service and feeder roads and other public amenities. To takeover the land required for these through eminent domain and award coupons embodying rights to development (transfer of development rights -TDRs for example) to such persons whose lands are so taken over. Builders and developers on lands elsewhere in the corridor who are free to develop in accordance with a plan perforce have to buy up these TDRs in a market in certain quantities that is related to the amount of construction or economic activity. This would ensure that those giving up lands are automatically rewarded ${ }^{27}$. These can be at sufficiently large values to remove fears of value loss in giving up land, when the ratios are correctly determined. TDRs can also be used to offset value changes than occur on zoning, and also to compensate for regulatory takings to preserve heritage and natural resources without being unfair to those whose lands are so restrained. TDRs were innovated only much after the economic transformation of Western Europe and America $^{28}$. But since much of the road construction, road-widening and more generally infrastructure construction lie ahead in countries such as India, there is much gain that can arise in lowering the frictions to development and changing land use, through the use of TDRs.

\section{Rehabilitation Issues}

Rehabilitation issues have been compounded by the inherent unfairness of the acquisition process. Correction of the same along with the internalisation of the cost of land, transactions and displacement into the project would go a long way towards better and risk reducing rehabilitation. Rehabilitation should never violate the principle of paretooptimality. This means that those currently displaced should be compensated to cover the value of land and their current incomes. But since partaking in growth is (or out to be a public good) their current incomes (rising at the planned or expected growth rates of the economy) needs to be protected. When we also recognise that given disguised unemployment alternative job opportunities cannot be assumed, So the onus would be on the project to ensure that incomes of all affected are protected at their expected dynamic levels.

Rehabilitation /compensation as a one time measure would not be suitable in all cases. Use of TDRs is possible to transfer the benefits to catchment area farmers (from command area farmers), who would otherwise lose through displacement, submergence, restraints on agriculture and more generally land use restrictions required to ensure low levels of siltation. Similarly land for land is also possible by using "land shrinkage" of

\footnotetext{
${ }^{27}$ Land owners would of course insist on a floor for the TDRs, which would be close to the current market price of the land. Assuming that sufficient enhancement of value takes place in the proposed economic activity it should always be possible, to specify such a floor. Indeed specifying a floor acts as a check on government, creating fiscal pressures and appropriate reputational stakes to ensure that projects are selected designed and managed in a way that maximizes social values. Since LDCs are growing rapidly, the situation of planning when functional, not resulting in large value enhancement would be rare.

${ }^{28}$ TDRs arose in the West more to protect environmental and heritage resources, and to control the declining densities. In India, in a crude form they are beginning to be used in Mumbai for slum `clearance’ with some success (Kothari, B. (2002)).
} 
now irrigated lands. Thus if the area of submergence is say $10 \%$ of the area that is irrigated then a TP like method that allows for farm shrinkage by around $10 \%$ of the command area would allow enough (now) irrigated land to be transferred to the displaced. Tribals and other marginalised people displaced in hydroelectric and irrigation projects could be vested with the residual rights to the assets potentialities created such as those related to fishing, tourism. This would allow tribals and their cooperatives or corporations paying rents to tribal organisations their cooperatives and corporations to charge rents and provide these services. In many instances there is a case to err on the side of overcompensation since in not having protests and political mobilisation vast delays and cost overruns that damage the very social viability of projects can be avoided. There is much to be learned from the examples of good land acquisition and rehabilitation such as in the case of NTPC's Simhadri Project near Vizag. [Morris, S., and Ajay Pandey (2005)]. They all highlight the point that the economics and justice aspects of acquisition have to be sound. The fact that these acquisitions and rehabilitations had to go beyond the law as such is further evidence that the law is in need of major overhaul.

\section{CONCLUSION AND WAY FORWARD}

Much of the risks and delays in land acquisition as also the protests that typically follow when substantial amounts of land are acquired arise out of the perversities inherent in the provisions of the LAA 1894 as amended in 1984.

Besides high transactions taxes, other measures not directly linked to the LAA but what we may club together under the term "regulatory restraints on land use" have significantly distorted the land markets depressing greatly the price of land currently under agriculture but with the potential to be used for non-agricultural purposes. Most notable has been the requirement of Non-Agricultural (Use) clearance.

Because the clearance is accorded typically post acquisition (post sale when no compulsory taking is involved) or along with the acquisition, the farmer/original land owner suffers much value denial, and creates vast rents to the acquirer or new owner post acquisition.

Similarly since there is no provision for "commutation of objections to the title" outside the provisions of the LAA 1884, there is considerable potential for "title arbitrage" to take place, i.e., for the post acquisition users to gain out of the now clear title.

The LAA while using eminent domain for compulsory takings, does not set up a process for either examination of the "public purpose" or for independent valuation of the land proposed to be taken over. Since the modification of the LAA (1984) government can acquire land for companies, i.e. all activities can come under public purpose as long as the government of the day thinks so. These create fiscal distortions and large opportunities for rent seeking.

The following changes in the LAA and in the framework of land acquisition /rehabilitation would be necessary to remove the major risks and perversities and ensure a fair process of land acquisition: 
The public purpose can and should be specified in the law as arising when specific land is required. Thus sites for dams and harbours, mines, road and other network industries would be specific lands. Similarly in the urban areas those activities that are crucially dependent upon access to central places and are typically not-appropriable would merit inclusion under public purpose. It is important to specify the public purpose ex-ante rather than leave acquisition acts open to challenge as is the case in the US. The option of not specifying the public purpose and not allowing challenge current in India is most undemocratic and gives excessively discretionary powers to the government and is one of important reasons for protest against the state.

Nevertheless options to take particular proposals (when outside the purpose specified exante) for land acquisition under eminent domain directly to the courts and or legislature need to be provided for to since not all public purposes can be seen in advance.

In the use of eminent domain the valuation of the land should not be carried out by the government but by independent professional bodies, and differences between such agencies when larger than $20 \%$ or so should go to arbitrators /courts for resolution.

All current restrictions on land use (other than those related to zoning of planning territories under urban development authorities) need to go. Most importantly the requirement of Non-Agricultural Use Clearance needs to go. Similarly the ban on the purchase of agricultural land for agricultural and other uses by non-agriculturalists, which is there in some states notably Gujarat and Maharashtra needs to go.

Transactions taxes cannot be at the punitive of $10 \%$ and above that they currently are ${ }^{29}$. They need to come down to less than $2 \%$ to allow smaller players also to use land as assets to buy and sell. If need be lower levels of government could be compensated for these tax losses. Similarly the tendency of mafias to be involved in land deals arises on account of the regulatory restrictions on land and the discretion available to the government to change these especially to award "NAC", besides the large transaction taxes.

The capitalised rental value of the land may be an underestimate of value even when all current distortions are removed and the value may be closer to the capitalised value of the value added in land given that disguised unemployment and considerable poverty still exists in large parts of the country.

Similarly in the valuation models, even in situations where the market is allowed to play its role, valuation of a specific piece of land in relation to another piece whose market price is available would have to recognise the value of natural resources especially water endowments that are accessible via the land and the intangible aspects of value such as nearness to central places and to transport networks.

There are many ways to carry out road widening, town planning, value enhancing investments like converting ribbon development to corridor development, providing public service through implicit acquisition, as in plot shrinking under "TP schemes" and in the use of "transfer of development rights" (TDRs). TDRs can also be used to make the

\footnotetext{
${ }^{29}$ These are probably above the revenue maximisation rates.
} 
process of town planning and corridor development fair to all the beneficiaries including those who give up their lands.

Rehabilitation issues have been compounded by the inherent unfairness of the acquisition process. Correction of the same along with internalising of the cost of land, and costs of transactions and displacement into the project would go a long way towards better and risk reducing rehabilitation.

Rehabilitation needs to be pareto-optimal. Those currently displaced should be compensated to cover the value of land, and their current incomes rising at the planned growth rates of the economy need to be protected, through compensation.

Independently of the LAA, measures to enhance the clarity with regard to title and to protect landed property would be important. A framework to allow any private owner of land to "commutate all objections to title" through due process would remove the scope for "title arbitrage" by the state and beneficiaries of state acquired lands. Similarly vastly better land records and registers, with their mortgage and other claims information, and their accessibility would go a long way to allow the markets to operate better and for an attenuation of the large role that mafias play in the land "market" today.

\section{Acknowledgement:}

The authors are grateful to the support provided by the UK High Commission. The views and analyses here are entirely those of the authors as individuals. 


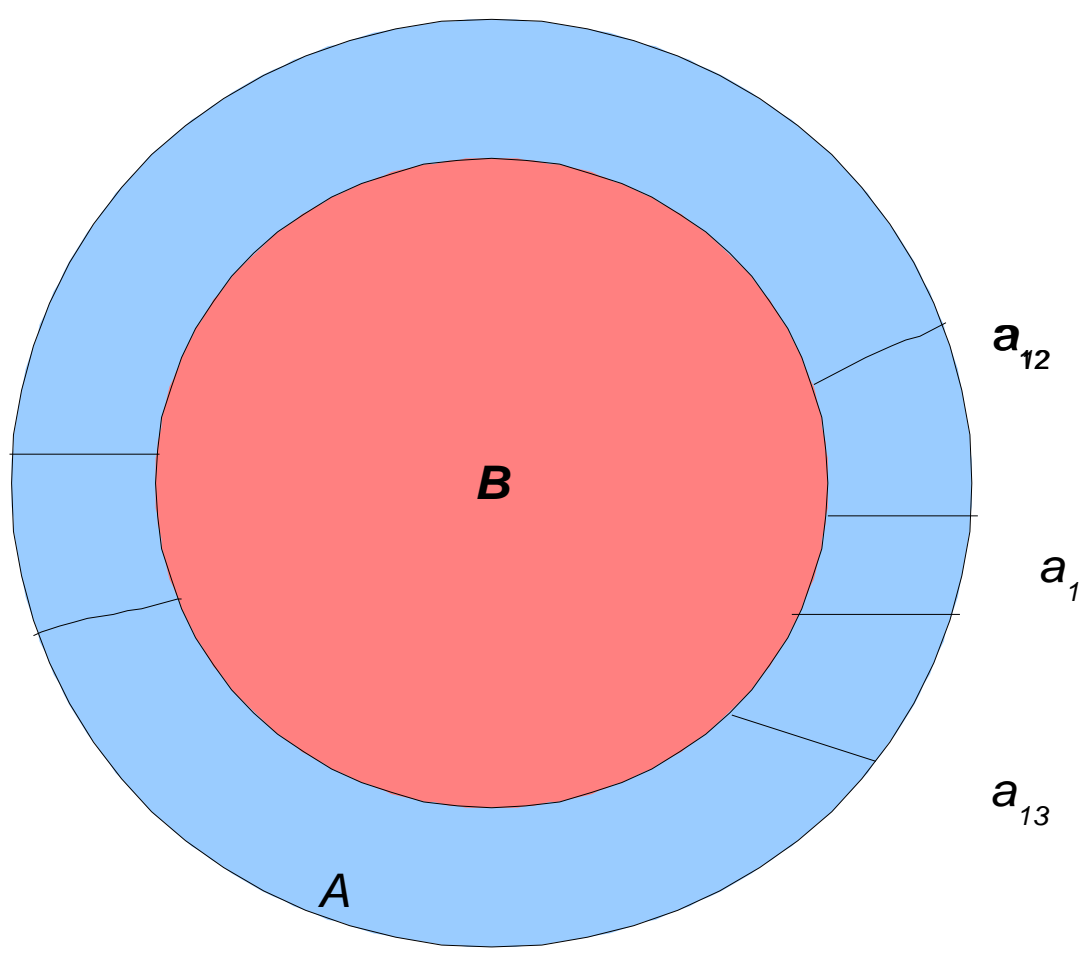

Fig.1:

Valuation of Pre and Post Taking in the Periphery of a Central Place 


\section{References}

Asif, M. (1999). Land Acquisition Act: Need for an Alternative Paradigm. Economic and Political Weekly, June 19, pp. 1564-1566.

Basu, Kaushik (ed.) (2007). The Oxford Companion to Economics in India A-Z”, New Delhi, Oxford Univ. Press.

Delhi-Janwadi-Adhikar-Manch (2002). The Assault on Workers in Land Use Policy and Practice in Delhi. in: Morris \& Shekhar (eds.) (2002).

Fernandes, W. (1998). Land Acquisition (Amendment) Bill, 1998: Rights of ProjectAffected People Ignored. Economic and Political Weekly, October 17-24, pp. 2703-2706.

Echeverria, John D. (2005), "Some Thoughts on Kelo and the Public Debate Over Eminent Domain”, Georgetown Environmental Law \& Policy Institute, July 22, 2005, mimeo.

(https://www.law.georgetown.edu/gelpi/current_research/documents/KeloMyth.pdf )

GOI (1985). The Land Acquisition Act, 1894 Government of India.

Kothari, B. (2002). Transfer of Development Rights: An Alternative to Conventional Land Acquisition. in: Morris \& Shekhar (eds.) (2002).

Machemer, P. L., J. Thomas, et al. (2000). Transferable Development Rights: A Policy Brief for the Michigan Legislature. Michigan State University. December 1, 2000.

Morris S., and Rajiv Shekar (eds.) (2004), India Infrastructure Report - Governance Issues for Commercialisation”, 3inetwork, Oxford University Press. New Delhi

Morris, S (2005), Sins of the highway programme's first phase haunt future planning Why the hurry for six-laning, even while four-laning is underway? Financial Express, October 11, 2005, http://www.financialexpress.com/fe_archive_full_story.php?content_id=105190

Morris, S. (2001), "Issues in Infrastructure Development Today: The Interlinkages” in Morris, S (ed.) (2001a)

Morris, S. (2006). One-sided law on land acquisition, Financial Express, June 20, (http://www.financialexpress.com/fe_full_story.php?content_id=131092)

Morris, S. (2007), “Infrastructure”, in Kaushik Basu (ed. ) (2007).

Morris, S. (ed.) (2001a), "India Infrastructure Report 2001: Issues in Regulation and Industry Market Structure", Oxford University Press, New Delhi, New York and Oxford, 2001, Chapter I Overview, and Chapter 2. Issues in Infrastructure Today. 
Ng, I. (2002). "Compulsory purchase and compensation in Hong Kong: A study of the role of the Land Development Corporation in Urban Renewal." Property Management 2(20): 167-182.

PUCL (1989). Enquiry into the Forcible and Illegal Land Sales and Acquisition for Industrial Purpose at Sarekhurd Village in Alwar District. Jaipur, Rajasthan. People's Union for Civil Liberties.

Rubin, H. J. (1988). "The Danada Farm: Land Acquisition, Planning and Politics in Suburbia." American Planning Association /The Journal of the American Planning Association 54(1): 79-90.

Shanin(ed.), T. (1971). Peasants and Peasant Societies. Middlesex, England, Penguin Books.

Sharma (1991). Land Grab, Bombay Style: Urban Development in Vasai-Virar Hinterland of Bombay. Economic and Political Weekly, February 23, pp. 413-417.

Sherry, J. E. H. (1996). "Land Regulation and Property Rights." Cornell Hotel and Restaurant Administration Quarterly 2(37): 16-17.

Srinivas, L. (1991). Land and Politics in India: Working of Urban Land Ceiling Act, 1976. Economic and Political Weekly, October 26, pp. 2482-2484.

Stevens, J. B. (1996). "Speculations: John Locke, Environmental Property and Instream Water Rights." Land Economics 72(2): 261-68.

Summers, Adam (2006), “Commentary Master of Your Domain: The Impact of the Kelo Decision. Why property rights are so crucial to freedom”, Reason.org, 26th June (http://www.reason.org/commentaries/summers_20060626.shtml).

World-Bank (1996). Ahmedabad: Land Use Issues \& Recommendations. World Bank. 